Esta publicación cientifica en formato digital es continuidad de la revista impresa ISSN-Versión Impresa 0798-1406 / ISSN-Versión on line 2542-3185Depósito legal pp
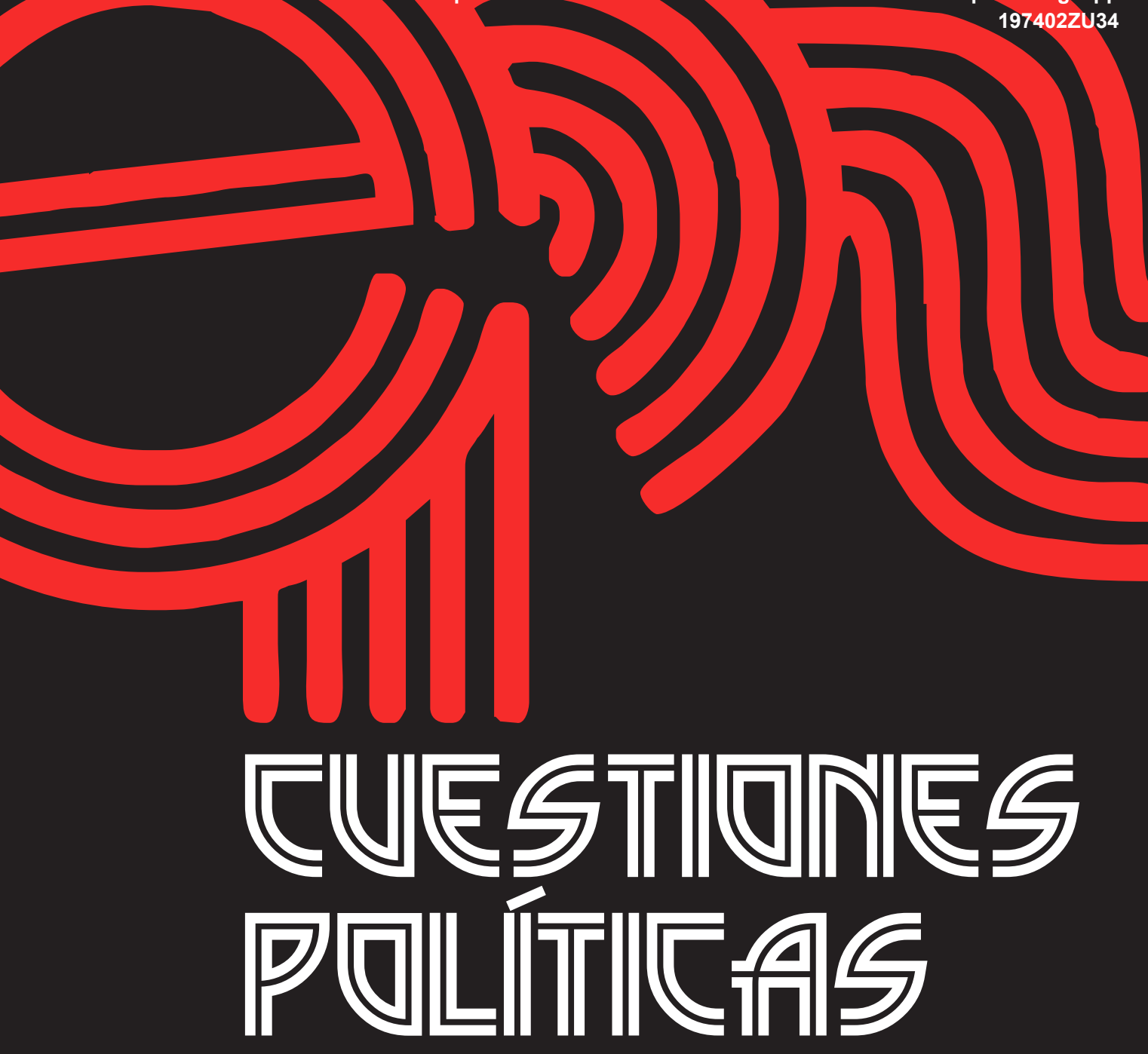

Instituto de Estudios Políticos y Derecho Público "Dr. Humberto J. La Roche" de la Facultad de Ciencias Jurídicas y Políticas de la Universidad del Zulia Maracaibo, Venezuela
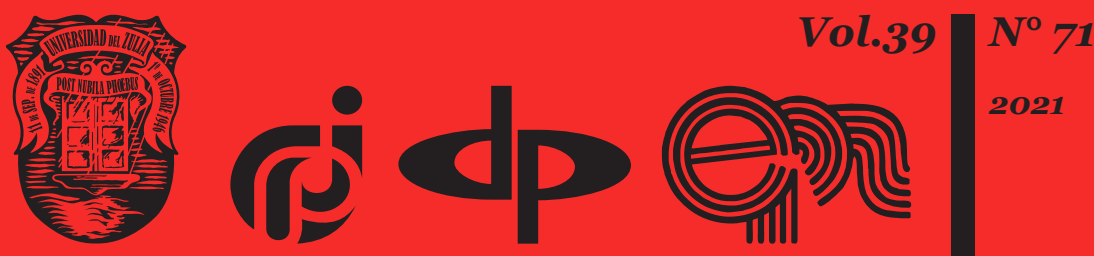


\title{
About the need to introduce a presumption of consent for organs transplantation and other human anatomical materials
}

\author{
DOI: https://doi.org/10.46398/cuestpol.3971.25
}

\author{
Liliya Popova* \\ Svitlana Popova ** \\ Hryhorii Krainyk *** \\ Iryna Bandurka **** \\ Olena Fedosova $* * * * *$
}

\section{Abstract}

The purpose of the article is to discuss the need to introduce a presumption of consent for the transplantation of organs and other human anatomical materials in Ukraine. Therefore, the object of the study is the presumption of consent for organ transplantation. The authors of the article have used methods of deduction, analysis and synthesis, comparative, and legal methods. The need to make amendments to the legislation of Ukraine regarding the introduction of the presumption of consent for the transplantation of organs and other human anatomical materials from a person and the feasibility of the practical implementation of these changes, namely, mean a major improvement and elimination of problems in the field of transplantation. It is concluded that at present one of the main problems governing the matter is the absence of presumption of consent for transplantation in Ukrainian legislation and, at the same time, the lack of significant funding of the medical sector, together with the low awareness of the rights of actors involved in organ transplant processes.

Keywords: presumption of consent; organ transplantation; human anatomical materials; medical help; presumption of consent.

* Department of Finance and Credit, Kharkiv National University of Civil Engineering and Architecture, Ukraine. ORCID ID: https://orcid.org/oooo-0oo1-8255-8363

** Department of Law Enforcement and Police Studies, Kharkiv National University of Internal Affairs, Ukraine. ORCID ID: https://orcid.org/oooo-0oo2-3958-4133

*** Department of Criminal-law Disciplines and Administrative Law, KHARKIV UNIVERSITY, Ukraine. ORCID ID: https://orcid.org/oooo-0001-7018-7710

**** Department of Criminal Law and Criminology, Kharkiv National University of Internal Affairs, Ukraine. ORCID ID: https://orcid.org/oooo-0002-9697-5587

***** Research Laboratory on Combating Crime Problems, Kharkiv National University of Internal Affairs, Ukraine. ORCID ID: https://orcid.org/oooo-0002-5577-8333 


\section{Sobre la necesidad de introducir una presunción de consentimiento para el trasplante de órganos y otros materiales anatómicos humanos}

\section{Resumen}

El propósito del artículo es discutir la necesidad de introducir una presunción de consentimiento para el trasplante de órganos y otros materiales anatómicos humanos en Ucrania. Por lo tanto, el objeto del estudio es la presunción de consentimiento para el trasplante de órganos. Los autores del artículo han utilizado métodos de deducción, análisis y síntesis, comparativos y métodos legales. La necesidad de realizar enmiendas a la legislación de Ucrania con respecto a la introducción de la presunción de consentimiento para el trasplante de órganos y otros materiales anatómicos humanos de una persona y la viabilidad de la aplicación práctica de estos cambios, a saber, significan una mejora importante y la eliminación de problemas en el ámbito del trasplante. Se concluye que en la actualidad uno de los principales problemas que rigen la materia es la ausencia de presunción de consentimiento para el trasplante en la legislación de Ucrania y, al mismo tiempo, la falta de financiación significativa del sector médico, junto a la baja conciencia sobre los derechos de los actores involucrados en los procesos de trasplantes de órganos.

Palabras clave: presunción de consentimiento; trasplante de órganos; materiales anatómicos humanos; ayuda médica; presunción de consentimiento.

\section{Introduction}

Particular attention is paid to the relevance and expediency of disclosing the issue of the need for organ transplants as a way of treating and saving human life, as well as studying the issue of Ukraine's experience regarding the presumption of consent for transplantation.

The article examines the experience of countries with a presumption of consent for organ transplantation and other anatomical materials, and the necessity of implementation of this practice in Ukraine is proved.

\section{Methodology and Methods}

The authors of the article have used methods of deduction, analysis and synthesis, comparative and legal methods. 
Each year in Ukraine more than 5 thousand people need transplants. Without waiting for a transplant, 7 people die every day. It is impossible to change the situation in Ukraine with transplantation of organs and tissues for the better without changes to the national legislation - first of all, Article 16 of the Law of Ukraine «On the application of transplantation of anatomical materials to a person» of 17 May 2018, which entered into force on January 1, 2019 (Law of Ukraine № 2427-VIII, 2018).

Section 7, paragraph 4, «Final and transitional provisions» of the Law of Ukraine "On the Application of the Transplantation of Anatomical Materials to a person» of May 17, 2018 stipulated that the Cabinet of Ministers of Ukraine before the enactment of this Law should ensure the development and approval of a number of by-laws required for its proper implementation, as well as to ensure the establishment and functioning of the Unified State Information System of Transplantation, the work of which involves the practical implementation of the provisions of the said Law (Law of Ukraine № 2427-VIII, 2018). That is, the Cabinet of Ministers of Ukraine and its subordinate Ministry of Health of Ukraine showed negligence and incompetence, which prevented from carrying out transplant operations in Ukraine from the 1 of January, 2019.

The purpose of the article is to prove the necessity of introducing a presumption of consent for organ transplantation and other human anatomical materials in Ukraine.

Researchers such as Krainyk H., Vakulovich E., Popova S., Sachuk B., Shklyarska O., Gel A. etc, after analyzing the experience of countries with a presumption of consent for transplantation, came to the conclusion that it should be supported by the introduction presumption of consent for organ transplantation and other anatomical materials in Ukraine (Krainyk and Sachuk, 2018; Krainyk et al., 2019; Shklyarska, 2017; Gel, 2018).

The article provides various arguments to support the introduction of the presumption of consent for transplantation in Ukraine, as well as the authors' suggestions on specific changes in the legislation of Ukraine concerning the solution of this issue are covered. At the same time, Trinova Y.A., Chebotareva G.V. and some other researchers oppose the presumption of consent for transplantation in Ukraine.

\section{Results and Discussion}

In some countries, there is a presumption of consent for transplantation (India, the United States of America, the Russian Federation, the Kingdom of Spain, the Republic of Poland etc.), which consists in the fact that every adult citizen of the state automatically becomes a posthumous donor, if 
during his life he did not express disagreement with the transplantation. The positive experience of these countries is based on the knowledge of psychology, when mostly young people (whose death can be caused by accidents in traffic accidents, in work or through fire-fighting injuries) do not think at all that they can die, especially since what will happen their organs, and therefore do not write the wills and do not give instructions to their relatives about the use of their organs after death.

As for the relatives of the deceased, they are primarily concerned with the burial issues and do not think that the bodies or tissues of their deceased relatives can save somebody's life, and some simply do not want to do this. Data from medicine show that often transplantation is the only chance to save people's lives. But there is one important detail on this issue: certain organs can be transplanted in just a few hours.

Article 3 of the Constitution of Ukraine states: «The person, his life and health, integrity and safety are recognized in Ukraine as the highest social value», Article 8 of the Constitution of Ukraine contains the provision that «Ukraine is a law-governed state, laws and regulations must comply with the Constitution» (The Constitution of Ukraine, 1996).

From this it follows that in case of non-compliance with the normative acts of the Constitution of Ukraine, they are subject to cancellation or bringing into compliance with the provisions of the Constitution of our state - the Constitution of Ukraine.

Consider the provisions of the Law of Ukraine «On the Transplantation of Bodies and Other Anatomical Materials to a person» from the 16 of July, 1999 (Law of Ukraine № 1007-XIV, 1999). Article 16 of this law contained the provision that a person should always consent to transplantation (this is a presumption of disagreement with transplantation). This law expired in January 2019. Instead, the provisions of the new Law of Ukraine «On the application of transplantation of anatomical materials to a person» from the 17 of of May, 2018 (which came into force in January 2019) also do not significantly change the situation with transplantation, since Article 16 also implies a presumption of disagreement on transplantation (Law of Ukraine № 2427-VIII, 2018), which does not meet the needs of Ukrainian society.

Currently, there are only five transplantation centers in Ukraine that carry out kidney, liver and heart transplantation operations (interesting fact is that over the past twenty years in Ukraine, only 8 heart transplants have been performed, if necessary, in 1000-1500 transplantations ), for comparison, in the Kingdom of Spain, for 47 million people, more than 40 transplantation centers, the average number of transplants ranges from 98 to 115 transplants per year (Krainyk and Sachuk, 2018).

Musienko A.V. recommends the adoption of standards regulating the organ and tissue transplantation, in accordance with the Guidelines 
Liliya Popova, Svitlana Popova, Hryhorii Krainyk, Iryna Bandurka y Olena Fedosova

developed by the World Health Organization and the World Health Organization, to organize bilateral and regional cooperation on the basis of the development of common standards, guided by the conventions and recommendations adopted by the Council of Europe, as well as bring domestic legislation in line with these general principles (Musiyenko, 2004).

Of great importance in considering the question of transplantation plays a religious factor. In Ukraine, according to religious beliefs, the majority are Christians (over 80\%). They are diametrically opposite to the question of transplantation. Some, recognizing the provisions of Article 3 of the Constitution of Ukraine, do not oppose transplantation and do not object to it, referring to the Bible's position on love for one's neighbor, the need to preserve the life of a Christian for his family and for the church. Another position is taken by the Russian Orthodox Church, the Moscow Patriarchate (in Ukraine, it calls itself the Ukrainian Orthodox Church), which has millions of Ukrainian citizens. She insists that transplantation is unacceptable. But at the same time, members of the church use the services of doctors, including in need of surgical intervention, and other benefits of civilization.

It should be noted that there are no scientifically substantiated arguments regarding the prohibition of transplantation or the presumption of consent for the transplantation of organs and other human anatomical materials in Ukraine from a legal, economic, or religious point of view.

From the legal point of view, the prohibition of transplantation or the prohibition of consenting to the transplantation of organs and other anatomical materials of a person contravenes Article 3 of the Constitution of Ukraine. From an economic point of view, such a ban is unprofitable for the church, since the money that may be earned by church ministers in the funeral ceremony is much smaller than those who would bring a Christian to a church for their lifetime (and in case of creation family - and his descendants). In any case, the church can still receive money at the human burial ceremony, but later.

From a religious point of view - there is no commandment in the Bible about the prohibition of transplantation, but there is a commandment to love one's neighbor as himself. Therefore, one should approach this issue with concrete proposals. Thus, some churches need to change their unconstitutional position; otherwise, those churches that carry out anticonstitutional activities and destructively affect the consciousness of Ukrainian citizens should be held responsible for violating the law. It is proposed to impose penal sanctions on such churches or even to close them when the church promotes, for example, the renunciation of medicine, the prohibition of transplantation. 
It is a fact that some Ukrainian citizens do not consider the possibility of transplantation through the mass media reports of «black transplantologists».

According to the Institute of the heart statistics, most Ukrainians are not ready to become donors. Only about $10 \%$ of respondents agreed to donate after death. Cardiac surgeon Boris Todurov, director of the Institute of the heart, believes that the reason for the ignorance of society, what is transplantology; unfortunately, in Ukraine, the majority of the media tell about transplantologists, as people who want to take away other organs, and represent transplantology as a science of organ harvesting. In fact, transplantology is a science of how to save incurably sick people. In 2010, criminal cases were opened on «black transplantologists». This undermined the credibility of all transplantation in society, although no evidence of guilty surgeons was given (Institute of Heart of Ukraine).

However, there are positive examples in Ukraine - one of the channels clearly explained in a number of reports that the presumption of consent for transplantation is very important for every citizen of the state, and that without a number of measures, including the register of transplant patients who need organ transplants, they threatened with inevitable death, while the dead bodies of their bodies are no longer needed.

The main arguments against the presumption of consent for transplantation are:

1. Religious. In some religions, there is a ban on transplantation of organs from a deceased donor, only a living person who has given consent to transplantation can be a donor. This prohibition operates in Judaism, Islam, Buddhism.

2. Legal. Possible violations of human rights during transplantation.

Chebotareva G.V. takes the stand against the presumption of consent for transplantation. The investigator concludes that the current legislation on transplantation «the model of the presumption of disagreement corresponds to the generally recognized international law of the legal provision on the need for a man's life consent to the removal of organs or tissues after her death, or the corresponding consent of the authorized persons after the death of a person and corresponds to world trends unification of legislation and the development of common standards of legal regulation in this area» (Chebotareva, 2003: 12-13).

Y. Trynova, after analyzing the pros and cons of the consent for transplantation, concluded that it would be appropriate to preserve the presumption of disagreement on transplantation, taking into account the risks to potential donors (Trynova, 2015). 
Liliya Popova, Svitlana Popova, Hryhorii Krainyk, Iryna Bandurka y Olena Fedosova 464

About the need to introduce a presumption of consent for organs transplantation and other human anatomical materials

However, Article 2, «Human Priority» of the Convention on Human Rights and Biomedicine (1999), states that «Individuals' interests and welfare prevail over the interests of society or science». The right of a person to provide disagreement is not violated by the legislative assertion of the presumption of consent for transplantation, since anyone who does not wish to become a donor in the future may indicate his reluctance to be specified in a will or in another accessible manner.

The main arguments for the presumption of consent for transplantation are: 1 . Lack of need for organs for a deceased person. The traces of operations under the clothes of the deceased will be invisible, but with cremation - are absent. 2. The existence of a religious aspect. The religious obligation of every Christian in some foreign countries to become posthumous donors. Thanks to Catholicism, the Kingdom of Spain came out first in the world in the number of post-mortem donors. Catholics are loyal to organs transplant from a deceased person, as well as engage in educational activities in this area. In the Kingdom of Spain, an educational program from the church began in the $1980-\mathrm{s}$ - the church talked about the need to become postmortem donors, calling it the responsibility of every Christian. 3 .

A sincere and unselfish desire to help others. 4. Existence of cases where only transplantation can save human life. 5. The level of awareness and awareness of people about transplantation needs to be improved. Often, people do not think at all that they can die, and even more so what to do then with their organs. Surveys show that most Ukrainian citizens do not mind giving their body to another person in case of death, but the vast majority of them do not agree to hand over organs to criminals. Therefore, this provision should be fixed legally in Article 16 of the Law of Ukraine «On the Application of the Transplantation of Anatomical Materials to a person» of the 17 of May, 2018. These arguments are clear and convincing, therefore they do not require additional explanation and justification.

Consider the arguments against the presumption of consent for transplantation:

1. Religious. In some religions (Judaism, Islam, Buddhism) prohibited transplantation from the deceased donor. However, the sacred books of these religions do not contain a direct prohibition on such transplantation, since at the time of their writing about transplantation was not discussed. One of the main tasks for each state is to ensure prosperity and decent living conditions and to protect the lives of its own citizens - we consider it expedient at the legislative level to oblige religious communities to permit the transplantation of organs and other anatomical materials, and in case of violation of the law, to bring these religious communities to liability. 
2. Legal. Regarding possible violations of human rights during transplantation, it can be noted that there are indeed certain risks of such a fact, but saving thousands of lives is more important than tolerating several possible violations. At the moment, when permission for transplantation is not a widespread phenomenon, there are even more different offenses and crimes in this area, because when there is an urgent need for organ transplant, there is also a donor, often in an illegal way. In order to prevent or at least minimize such violations, it is advisable to introduce open access to the list of transplant recipients and donor lists to prevent violations of current transplant legislation.

The Law of Ukraine «On Amending Certain Legislative Acts of Ukraine on the Application of the Transplantation of Human Anatomical Materials» from the 28 of February, 2019 postponed the entry into force of the provisions on the establishment of a donor register by the 1 of January, 2020 (Law of Ukraine № 2427-VIII, 2019).

In the current edition of Art. 16 of the Law of Ukraine «On the application of transplantation of anatomical materials to a person» dated by the 17 of May, 2018 reads as follows: «Every adult legal person can give written consent or disagreement to become an donor of anatomical materials in case of his death. In the absence of such an application, anatomical materials in a deceased adult capable person may be taken with the consent of the spouses or relatives living with her until death. Anatomical materials may be taken with the consent of their legal representatives in deceased minors, disabled or incapacitated persons».

An individual has the right to order the transfer of organs and other anatomical materials of her body to scientific, medical or educational institutions after her death.

In case of need for forensic examination, the anatomical materials of the deceased donor are taken with permission and in the presence of a forensic medical expert. The taking of anatomical materials should not compromise the conduct of pre-trial investigation, and forensic medical expert must inform the head of the local prosecutor's office within twenty-four hours.

The taking of anatomical materials from a deceased donor should not result in distortion of his body. The taking of anatomical materials from a deceased donor is made by an act. This act is signed by doctors who took part in the taking of anatomical materials, and in the case of forensic medical examination - and forensic medical expert, and attached to the medical documents of the deceased person. The taking of anatomical materials in a deceased person for transplantation and (or) for the manufacture of bioimplants is not permitted in the event of a statement made by that person during the lifetime of his disagreement as a donor. 
Liliya Popova, Svitlana Popova, Hryhorii Krainyk, Iryna Bandurka y Olena Fedosova 466

About the need to introduce a presumption of consent for organs transplantation and other human anatomical materials

In the deceased adult legal person whose application for donation is absent, as well as in minors, disabled and incapacitated persons, the taking of anatomical materials is not allowed, if it is not received or impossible to obtain the consent of the persons specified in part one of Article 16 of the Law of Ukraine "On application transplantation of anatomical materials to a person». The taking of anatomical materials in a deceased person is also not allowed in the absence of a permit of a forensic expert in case of necessity of forensic medical examination».

Despite the available human and scientific potential, the development of clinical transplantology in Ukraine has slowed down in the last decade. The revival of domestic transplantation is possible only due to a combination of state policy, active work of public and charitable organizations, persistent work of general practitioners and representatives of the Ministry of Health of Ukraine. Therefore, the most important thing now is to create a legislative foundation and provide an effective and efficient mechanism for regulating and implementing transplants. Also, with a huge demand for such operations, they are very few, and public funds are spent on treatment of citizens abroad, although in Ukraine it would be much cheaper (Krainyk and Sachuk, 2018: 700).

It is worth mentioning that in 1933 the Ukrainian surgeon Yuriy Voron performed a successful kidney transplant of a deceased person. This operation was the first of its kind. However, today in Ukraine more than 5 thousand people are being treated for acute and chronic renal failure with the help of an artificial kidney device, and some of them are waiting for a kidney transplant. Today, there are only five transplant centers in Ukraine that perform kidney, liver and heart transplants. Compared to Spain, there are more than 40 transplant centers per 47 million population, and the average number of transplants ranges from 98 to 115 transplants per year.

One of the problems of transplantology in Ukraine is the lack of donors, both living and dead. Living potential donors rarely agree because they take care of their own health, and for the dead, according to rough statistics, there are about 3,00o people killed in road accidents in Ukraine each year, as well as about a thousand dead each year in Operation United forces and more than 1,00o suicides. In Ukraine, transplantation from a living family donor predominates, and transplantation from a corpse donor has hardly been practiced in recent years. Therefore, in recent years (2016 - 2020) no more than ten kidney transplants were performed from a cadaveric donor. And in countries with a well-developed transplant system, there are 14-39 cadaveric donors per 1 million population, while in Ukraine in 2016 it was 0.2 people per 1 million population.

Therefore, in Ukraine, in our opinion, it is necessary to create a single state information system of transplantation, which will have a convenient register of patients, and in which every citizen of the state will be able to 
consent or disagree to donate and thus save someone's life. For this purpose, Art. 14 of the Law of Ukraine "On the use of transplantation of anatomical materials to humans." This is very important because, according to clinical studies, transplants from a living donor are safer for the recipient and take root better.

Ukraine can also borrow the experience of a "donor card", as in the United States. The procedure for obtaining a "donor card" is usually carried out when issuing a driver's license, and in Ukraine it would be advisable to carry out a similar procedure when a citizen receives a driver's license and at the time of conscription. Data on this are not registered, so in case a person changes his decision, the "donor card" can simply be destroyed. thus, it will help raise public awareness, give the right to choose and the opportunity to save others.

Worldwide, transplantation of human organs and biological materials is one of the most effective, and sometimes unalterable, ways to save lives. Most irreversible damage to vital organs such as the kidneys, liver, pancreas, lungs and heart cannot be cured other than by surgery. That is why transplantology in the developed countries of the world is one of the most dynamically developing areas, according to the Chairman of the Parliamentary Committee on Health - Olga Bogomolets (Nikonenko, 2014). The global growth rate of transplant operations predicts that in 20-30 years, 50-60\% of all surgeries will involve transplantation of organs, tissues and cells, in addition, will no longer transplant organs, but artificially or artificially grown.

Up to 100,000 organ transplants and more than 200,000 human tissue and cell transplants are performed annually worldwide. Today, there are more than 1 million people with transplanted organs in the world, and their number is constantly growing.

Today, there is no country on the planet where transplantation is banned. According to the World Health Organization, it is held in 104 countries around the world, which have the financial, logistical and human resources.

Statistics show the effectiveness and popularity of transplantation as the most effective treatment for irreversible diseases of the organs. Thus, about 26-28 thousand transplants are performed annually in the United States, in the Kingdom of Spain - more than 4 thousand, in the Republic of Poland - more than 1.5 thousand. In Estonia, this figure is 46.2 transplants per 1 million population, in Latvia - 36.2, in Lithuania - 22.

The situation in Ukraine can be called catastrophic, even compared to its neighbors. According to the statistics of 2018, we perform only 3.1 transplants per 1 million population per year. And this is one of the worst indicators in the world (Bogomolets, 2018). 
Liliya Popova, Svitlana Popova, Hryhorii Krainyk, Iryna Bandurka y Olena Fedosova 468

About the need to introduce a presumption of consent for organs transplantation and other human anatomical materials

In absolute numbers, this is only 130 operations per year, despite the fact that more than 5,000 Ukrainians need organ transplants every year. Of these, more than 2,500 patients need kidney transplants, up to 1,500 patients need liver transplants, more than 1,000 patients need heart transplants, and 300 people need bone marrow transplants.

The number of people in need of surgery is growing steadily, and most of them die without waiting for a transplant. Of the 5,000 people in need of a transplant, about 3,400 die each year. O. Shklyarska (2017:15) quotes: "Every day in Ukraine, nine people die without waiting for a transplant." Those who are lucky are sent abroad by the state, spending millions of hryvnias to pay for the services of foreign doctors. With the funds that Ukraine transferred to foreign clinics for the treatment of our citizens in 2013-2015 ( $\$ 2.431$ million and 612.2 thousand euros), 6 bone marrow transplants, 8 heart transplants, 5 liver transplants and 18 kidney transplants were performed. With a well-established transplant system in Ukraine, 1122 heart transplants could be performed with these funds, 116 liver and 5623 - kidney (Shklyarska, 2017).

A few words need to be said about the norm of the following content, which is enshrined in Part 5 of Art. 13 of the Law of 17.05.2018: "If the recipient is in an urgent condition, which is a direct and imminent threat to his life, medical care with the use of transplantation is provided without the consent of the recipient, his parents or other legal representatives." According to A. Gel, the norm is as follows: first, it restricts the personal non-property rights of the recipient and his parents (legal representatives) in terms of the right to consent to medical intervention, and secondly, directly contradict the requirements set by the legislator in Part 2 of Art. 43 Fundamentals of the legislation of Ukraine on health care (1992) (Consent to medical intervention). We quote this rule:

The consent of the patient or his legal representative to medical intervention is not required only in the presence of signs of direct threat to the patient's life, provided that it is impossible for objective reasons to obtain consent for such intervention from the patient or his legal representatives (Fundamentals of the legislation of Ukraine on health care, 1992: n/p)

Thus, the legislator explicitly determines that the implementation of medical intervention without the consent of the relevant entity is possible only if there are two necessary conditions: a) the presence of a direct threat to the patient's life; b) the lack of objective reasons to obtain such consent. We share the opinion of A. Gel that this is exactly the wording that the legislator should have used in constructing the norm enshrined in Part 5 of Art. 13 of the Law of 17.05.2018. At the same time, the norms of special medical legislation do not look very correct, which directly contradict the requirements of the Fundamentals of Legislation of Ukraine on Health Care - the basic legislative act that defines legal, organizational, economic and 
social principles of health care in Ukraine, and is essentially nothing more than a "constitution of a medical worker" (Gel. 2018: n/p).

Such an edition of the article requires urgent changes, since it does not solve the issue of saving the lives of Ukrainian citizens due to the lack of donor agencies' contributions from corps donors.

Other issues that require urgent resolution are the creation of the Uniform Register of Donors and Recipients, the preparation of subnormative acts on transplantation etc.

\section{Conclusions}

1. The necessity of making amendments to the legislation of Ukraine regarding the introduction of the presumption of consent for transplantation of organs and other human anatomical materials of a person and the feasibility of practical application of these changes, namely, significant improvement and elimination of problems in the transplantation sphere, is grounded, one of the main is the absence of presumption of consent for transplantation in the legislation of Ukraine and significant underfunding of the medical sector, low awareness and «transplantation» of illiteracy of citizens.

2. Given that one of the major opponents of transplantation is the church that affects the consciousness of not only ordinary citizens of Ukraine, but also of state authorities of Ukraine, one must ask the following question: either some churches (the Ukrainian Orthodox Church (which is essentially a part of the Russian Orthodox Church churches of the Moscow Patriarchate), Jehovah>s Witnesses, etc.) change in Ukraine their unconstitutional position on the prohibition of transplantation or presumption of consent for transplantation, or they are legally liable in the territory of Ukraine as such anticonstitutional activity and destructively affect the consciousness of Ukrainian citizens.

3. Article 16 of the Law of Ukraine «On the Application of the Transplantation of Anatomical Materials to a person» from the 17 of May 2018, is proposed to be worded as follows: «Every adult legal person may give written consent or disagreement to become an donor of anatomical materials in case of his death. In the absence of a statement of disagreement with the transplant, consent from relatives or others is not required. In this case, deceased persons are deemed to have given consent to the transplantation of anatomical materials». 
Liliya Popova, Svitlana Popova, Hryhorii Krainyk, Iryna Bandurka y Olena Fedosova

470

About the need to introduce a presumption of consent for organs transplantation and other human anatomical materials

4. In Ukraine, in our opinion, it is necessary to create a single state information system for transplantation, which will have a convenient register of patients, and in which every citizen of the state will be able to give their consent or disagreement to donate and thus save someone's life. For this purpose, Art. 14 of the Law of Ukraine " On the Application of Transplantation of Anatomical Materials to a person".

\section{Bibliographic References}

THE CONSTITUTION OF UKRAINE. 1996. Vidomosti Verkhovnoi Rady Ukrayiny. No 30. Art. 141.

LAW OF UKRAINE № 1007-XIV. 1999. About Transplantation of Organs and Other Anatomical Materials to a person. Vidomosti Verkhovnoi Rady Ukrayiny. No 41. Art. 377.

LAW OF UKRAINE № 2427-VIII. 2018. On the Application of Transplantation of Anatomical Materials to a person. Available online. In. http://zakon3. rada.gov.ua/laws/show/2427-19. Date of consultation: 30/03/2021.

KRAINYK, Hryhorii; SACHUK, Bogdana. 2018. "Problematics of development of transplantation in Ukraine" In: Young scientist. Vol. 56, No 4, pp. 700703.

MUSIYENKO, Anatolii. 2004. "Transplantation of organs and tissues. Problematic aspects of legal regulation in Ukraine" In: Prokuratura. Lyudyna. Derzhava. Vol. 35, No 5, pp. 84-88.

CHEBOTAREVA, Galina. 2003. Criminal-legal problems of transplantation of human organs or tissues and blood donation: author's abstract to dissertation... candidate of law sciences: 12.00.08. Institute of State and Law named after V.M. Koretsky. 18 p. Kyiv, Ukraine.

TRYNOVA, Yana. 2015. "Bioethics: transplantology. Presumption of disagreement vs presumption of consent" In: Yurydychnyy visnyk Ukrayiny, pp. 19-20.

CONVENTION ON HUMAN RIGHTS AND BIOMEDICINE. 1999. Available Online. In. https://www.coe.int/en/web/conventions/ full-list/-/conventions/treaty/164?_coeconventions_WAR_ coeconventionsportlet_languageId=ru_RU. Date of consultation: 30/03/2021. 
INSTITUTE OF HEART. Undated. Official website of the Heart Institute of the Ministry of Health of Ukraine. Available online. In. http://www.heart. kiev.ua/. Date of consultation: 30/03/2021.

KRAINYK, Hryhorii; POPOVA, Svitlana; VAKULOVYCH, Elana. 2019. "Problems of transplantation developme nt in Ukraine" In: Wiadomosci Lekarskie. Vol. 21, No 3, pp. 457-461.

LAW OF UKRAINE № 2427-VIII. 2019. On Amending Certain Legislative Acts of Ukraine on the Application of the Transplantation of Human Anatomical Materials. Available online. In. http://search.ligazakon. ua/1_doc2.nsf/link1/T192694.html. Date of consultation: 30/03/2021.

NIKONENKO, Oleksandr. 2014. "Transplantation service of Ukraine: problems of development and ways to overcome them (Nikonenko, OS, Salyutin, RV, Komarov, MP, Palyanytsya, SS)" In: Cellular and organ transplantology. Vol. 2. No 1, pp. 155-170.

BOGOMOLETS, Olha. 2018. Newspaper "Mirror of the Week". № 17, the 12-18 of May, 2018. Available online. In. https://dt.ua/HEALTH/ transplantologiya-v-ukrayini-vidstala-vid-svitu-na-cilu-epohu-277485. Date of consultation: 30/03/2021.

SHKLYARSKA, Oksana. 2017. "Rejection, or what future awaits transplantation in Ukraine?” In: Legal Bulletin of Ukraine. No 6-7, pp. 10-23.

GEL, Andrij. 2018. Transplantation. Legislative innovations in this area: a first look. Available online. In: lexinform.com.ua/dumka-eksperta/ transplantatsiya-novatsiyi-zakonodavtsya-u-tsij-sferi-pershyj-poglyad/. Date of consultation: 30/03/2021.

LAW OF UKRAINE № 2801-XII. 1992. Fundamentals of The Legislation of Ukraine on Health Care. Vidomosti Verkhovnoi Rady Ukrayiny. No 4, Art. 19. 
Vol. 39 N $^{\circ} 71$

Esta revista fue editada en formato digital y publicada en diciembre de 2021, por el Fondo Editorial Serbiluz, Universidad del Zulia. Maracaibo-Venezuela 